\title{
ON THE NECESSITY FOR AND THE LIMITS OF POLITICAL APOLOGIES IN POST-1989 EASTERN GERMANY
}

\author{
MARIA PALME \\ EUROPA-UNIVERSITY FLENSBURG
}

\begin{abstract}
Since the 1990s, the making of an apology has become an instrument for promoting international and national reconciliation, replacing the exaction of vengeance upon the officials of former non-democratic regimes. This article explains when and under what circumstances an explicit apology for political wrongs has contributed to overcoming divisions in post-socialist German society. It specifically focuses on politicians and political parties that have direct links and continuity with the former oppressive regime in East Germany. What role and what impact have political apologies had on the victims to whom they are addressed and on public discourse generally? Are they part of a broader acknowledgment of past injustices under the German Democratic Republic (GDR) dictatorship? Adopting a discourse analysis approach, this paper outlines the historical and political conditions, the intentions and the outcomes of speeches of political apology in eastern Germany. It focuses on the narratives of GDR officials, Stasi informants, and members of Die Linke (The Left), a successor party to the GDR's ruling communist Socialist Unity Party (SED), and on the responses to those narratives from the new elites, former dissidents in the GDR, and groups representing the victims of communism. The article concludes that political apologies expressed by state officials who were formerly linked with the oppressor state stimulate a dialectical process with regard to past injustices, even if they fail to achieve the desired reconciliation.
\end{abstract}

Keywords: political apology; reconciliation; collective memory; Germany; communism DOI: $10.14712 / 23363231.2019 .11$

Maria Palme is a PhD student at Europa-University Flensburg. Supervisor: Prof. Dr. Ralf Wüstenberg. Address correspondence to Institute of Social Sciences and Theology, Auf dem Campus 1, D-24943 Flensburg. E-mail: Maria.Palme85@gmail.com. 


\section{Introduction}

In the final, closed door hearing of the German parliamentary History Commission, held on June 17, 1994 and titled "Working through the History and Consequences of the Dictatorship of the Socialist Unity Party of Germany (Sozialistische Einheitspartei Deutschlands, SED)," Dietmar Keller (born 1942) apologized before the Bundestag in Bonn:

These hearings were the most bitter hours of my life, primarily, because not only did I know not all, but also because I understood what happened in the name of Socialism with my ideals and beliefs, my hopes and my wishes, and how they were abused. As a member of the German Enquête Commission for the Party of Democratic Socialism (PDS) it is my moral duty and responsibility to apologize to all victims of the one-party dictatorship of the SED. ${ }^{1}$

Keller was the GDR's Minister of Cultural Affairs under the communist dictatorship. He became a member of the German Bundestag after reunification in 1990 as a representative of the leftist Party of Democratic Socialism (PDS), the successor party to the communist SED, which ruled East Germany from 1949 to 1989. Keller was one of the few participants in the history commission who was a former GDR official. He showed deep remorse over past communist crimes. All the factions of the German Bundestag accepted his symbolic apology and greeted it with applause.

After the Cold War ended, political apologies ${ }^{2}$ became an accepted tool for international and intra-national political reconciliation. They were promoted by United Nations organizations with that aim in mind. The International Center for Transitional Justice (ICTJ) defines a public apology as a "symbolic gesture of reparation" and an "acknowledgment of past crimes.” A public, political apology

1 Deutscher Bundestag, ed., Enquete-Kommission "Aufarbeitung von Geschichte und Folgen der SED-Diktatur in Deutschland" (12. Wahlperiode des Deutschen Bundestages), Vol. 1: Enquete-Kommission: Anträge, Debatten, Bericht (Baden-Baden: Suhrkamp, Nomos, 1994), 813.

2 "Political apology" refers to an apology offered to the public domain. It is consequently widely publicized. See Sandra Harris, Karen Grainger, and Louise Mullany, "The Pragmatics of Political Apologies," Discourse \& Society 17, No. 6 (2006): 715-757, here 720, doi: $10.1177 / 0957926506068429$. Consequently, this article uses the terms "political apology" and "public apology" synonymously. 
is one more tool for achieving societal reconciliation, along with rehabilitation, restitution, medical and psychological care, and institutions like "history" or "truth and reconciliation" commissions. ${ }^{3}$ Some scholars even argue that we have entered a "new age of apology."

These efforts at reconciliation emerged in the wake of the collapse of communist and other non-democratic regimes at the end of the Cold War. Optimists see in reconciliation a chance for an end to an unforgiving bipolar world and the beginning of a new world order where individuals and collectives accept their moral and political responsibility for past injustices. ${ }^{5}$ According to Christopher Daase, an apology can "restore the self-respect and human dignity of the victims by acknowledging their suffering, and it can relieve the perpetrator from feelings of guilt and self-contempt by paying respect to the victim and acknowledging the perpetrator's own wrongdoing." 6 Additionally, political apologies set the stage for a new national master-narrative or a dialogue that emphasizes reconciliation instead of vengeance between former antagonists. Detractors see such apologies as a cynical ploy by former oppressor groups to extort "forgiveness" and to "forget the past." They view apologies as an "empty ritual" with a destructive effect on the process of national reconciliation. ${ }^{7}$

Indeed, a number of negative examples substantiate the latter opinion, such as the Spanish transition from 1975 to 1982 and the Argentinean amnesties at the beginning of the 1990s. Other examples are self-serving speeches made by Eastern European leaders such as the one given in 2006 by Romania's President Basescu, a former member of the Romanian Communist Party, where he urged national reconciliation prior to Romania joining the European Union. ${ }^{8}$ On the

3 “Reconciliation," International Center for Transitional Justice, https://www.ictj.org/gallery-items /reconciliation.

4 Robert R. Weyeneth, "The Power of Apology and the Process of Historical Reconciliation," The Public Historian 23, No. 3 (Summer 2001): 9-38, doi: 10.1525/tph.2001.23.3.9.

5 Christopher Daase, "Entschuldigung und Versöhnung in der Internationalen Politik," Aus Politik und Zeitgeschichte, No. 23-24 (2013): 43-49, http://www.bpb.de/apuz/162893/entschuldigung-und-versoehnung-in-der-internationalen-politik? $\mathrm{p}=$ all; Joseph V. Montville, "The Healing Function in Political Conflict Resolution," in Conflict Resolution Theory and Practice, ed. Dennis J. D. Sandole and Hugo van der Merwe (New York: Manchester University Press, 1993), 112-127.

6 Christopher Daase, Stefan Engert, and Judith Renner, "Introduction," in Apology and Reconciliation in International Relations, ed. Christopher Daase et al. (London: Routledge, 2016), 1-29, here 12 .

7 Judith Renner, "A Discourse Theoretic Approach to Transitional Justice Ideals: Conceptualizing 'Reconciliation' as an Empty Universal in Times of Political Transition," Critical Perspectives in Transitional Justice 8 (2012): 51-73, here 52-54.

8 "Speech by the President of Romania, Traian Basescu, to the Parliament of Romania on 18 December 2006, given on the Occasion of the Presentation of the Report by the Presidential Commission 
other hand, some current experience proves the potential of political apologies to foster national reconciliation. Such apologies can serve not only as tools for social transformation and defusing of antagonistic relations between former enemies, ${ }^{9}$ but also as a stimulant for a dialectical process that reveals and reinterprets the deeds of past dictatorships in the hope of influencing collective memory. ${ }^{10}$ According to Judith Renner, reconciliation "creates a space for collective action and political and social mobilization." 11 This paper argues the reconciliation process in the post-communist societies has brought about a paradigm shift after which the narrative of the past injustices is created through a dialogue between the antagonistic groups.

In 1995, French President Jacques Chirac (born 1932), who is a member of the generation that was alive when the Holocaust took place, expressed his regret - fifty years after the fact - for the deportation by the collaborationist Vichy regime of more than 75,000 Jews to German death camps during World War II. ${ }^{12}$ His remarkable speech marked the end of a one-sided, victim-centered interpretation of the past in France. It was followed by a vibrant public discourse between the generations about French citizens' collective responsibility for the crimes of the Holocaust era.

Decades later, a few speeches of apology were made by Eastern European former Communists, in which they regretted the crimes committed under socialist regimes. However, those speeches had less impact in Eastern Europe and Germany than in France, with only some exceptions. One example of such an apology was a speech by Aleksander Kwaśniewski, the leader of the Polish Democratic Left Alliance (SLD) and later President of Poland, on November 11, 1993. His speech was exceptional and heralded a new, consensual approach

for the Analysis of the Communist Dictatorship in Romania," Honorary Consulate of Romania (Boston, Massachusetts), http://www.roconsulboston.com/Pages/InfoPages/Commentary/Communism/BasescuSpeech.html.

9 Lily Gardner-Feldman, Germany's Foreign Policy of Reconciliation (Lanham, MD: Rowman and Littlefield, 2012), 10.

${ }^{10}$ Dialectic refers to the Hegelian theory that describes a certain method based on a contradiction of ideas and arguments followed by a synthesis, see Georg W. F. Hegel, Encyclopedia Logic. Part I: Encyclopedia of Philosophical Science, transl. by T. F. Geraets, W. A. Suchting, and H. S. Harris (Indianapolis and Cambridge: Hackett Publishing Company Inc., 1991), 124. See also Renner, "A Discourse Theoretic Approach," 54.

11 Renner, "A Discourse Theoretic Approach," 70.

12 Marlise Simons, "Chirac Affirms France's Guilt in Fate of Jews," The New York Times, July 17, 1995, https://www.nytimes.com/1995/07/17/world/chirac-affirms-france-s-guilt-in-fate-of-jews.html. 
in Poland to the transition from old to new political elites. ${ }^{13}$ He expressed deep remorse and his emotional appeal was met with wide acceptance by leaders of the former opposition to the communist regime, by Christian Democrats and by the victims of oppression. ${ }^{14}$

This paper will focus on the effect of political apologies, such as their potential to either reveal or conceal past injustices. It will make use of the experience of eastern Germany after reunification. It will seek an answer to the question, how do political apologies contribute to reconciliation?

Eastern Germany ${ }^{15}$ is a promising example for analyzing the effectiveness of political apologies in terms of reconciliation and accountability for the acts of former communist dictatorships. Firstly, East Germany's short, peaceful democratic transformation after $1989^{16}$ and its integration into West Germany's legal framework created an ideal basis for an effective accounting for the deeds of the communist state. ${ }^{17}$ Germany is a role model, a "world champion in working through the past" 18 compared to its formerly socialist neighbors, which faced more fragile power relationships and difficulty in finding political compromises in their post-communist existences. Most of the former elite in public service

13 Carlos Closa Montero, "Study on How the Memory of Crimes Committed by Totalitarian Regimes in Europe is Dealt with in the Member States" (Study commissioned by the European Commission and completed in January 2010), fol. 140, http://digital.csic.es/bitstream/10261/34366/1 /Closa_Memory_of_crimes.pdf.

${ }^{14}$ Linnet Myers, "Polish Leftist Sorry for Old Party's Abuses," Chicago Tribune, November 10, 1993, http://articles.chicagotribune.com/1993-11-10/news/9311100158_1_parliamentary-election-solidarity-apology.

15 The term "eastern Germany" is used to describe the eastern parts of unified Germany as opposed to the term "East Germany," a colloquial name for the German Democratic Republic (GDR), which existed between 1949 and 1989.

16 The historical break of 1989 reflects the internal German perspective. It stands symbolically for the end of the Cold War that began with the fall of the Berlin Wall on November 9, 1989. According to studies by Huntington, this historical event needs to be interpreted in the context of the "third wave of democratization." This series of political transitions away from autocratic states started in Europe with the "Carnation Revolution" in 1974, which deposed the fascist regime in Portugal. It influenced events in Latin America, East Asia and Eastern Europe after the collapse of the Soviet Union. See Samuel Huntington, The Third Wave: Democratization in the Late Twentieth Century (Norman: University of Oklahoma Press, 1991).

17 A. James McAdams, Judging the Past in Unified Germany (Cambridge: Cambridge University Press, 2001), 4.

18 This reference to Germany as the Weltmeister der Vergangenheitsbewältigung (world champion in working through the past) is found in a speech given by German Book Trade Peace Prize Winner Péter Esterházy. See Katrin Hammerstein and Julie Trappe, "Aufarbeitung der Diktatur - Diktat der Aufarbeitung. Einleitung," in Aufarbeitung der Diktatur - Diktat der Aufarbeitung. Normierungsprozesse beim Umgang mit diktatorischer Vergangenheit, ed. Katrin Hammerstein et al. (Göttingen: Wallenstein, 2009), 9-21, here 9. 
was replaced in post-socialist eastern Germany following passage of the lustration law of 1991. Consequently, the old political and official elites were all disempowered within a short span of time. Multiple acts of transitional justice, such as the Border Guard Trials (1991-2004) and the Politburo Trials (1995-2000) took place, but they had little success in healing the old wounds of communism's victims. Many of the prosecutions were only symbolic; most of the individuals who were directly responsible for past injustices could not be punished and those who were received only a few years in prison. For instance, there were a total of 280,000 known collaborators with the Stasi, the central executive organ of state repression, which was responsible for building more than 40 years of distrust within East German society. The SED, the leading Marxist-Leninist political party, had more than 2.3 million members. Yet only 224 persons were ever convicted in German courts on account of political crimes and human rights violations. ${ }^{19}$

After 1990, the criminal law and the political process did not meet the high expectations for justice of the communist regime's victims. Nevertheless, multiple rehabilitation and restitution laws have been passed since 1995 to compensate the victims of the state's violations of human rights. Of an estimated 200,000 persons arrested by the communist regime for political crimes, ${ }^{20}$ about 80,000 have been officially rehabilitated. ${ }^{21}$ Another 100,000 who were not arrested but experienced other forms of oppression (e.g., by being banned from employment) have been compensated. ${ }^{22}$ The legal responsibility for righting the injustices committed by the GDR communist regime has been transferred to today's Federal Republic of Germany; as a result, a one-sided dissidents' perspective has become the national master-narrative in reunified Germany. As Andrew Beattie aptly put it, "a focus on questions of integrity, morality, and truth relating to individual or group behavior within (or toward) the GDR does not engage with

19 Constantin Goschler, "German Reunification and the Challenge of Transitional Justice," in Transitional Justice in Unified Korea, ed. Baek Buhm-Suk and Ruti G. Teitel (New York: Palgrave MacMillan, 2015), 123-137, here 127; see also Ruth Gleinig and Anna Kaminski, eds., Übersicht über Beratungsangebote für Opferpolitischer Verfolgung in der SBZ/DDR, 5th edition (Berlin: Bundesstiftung zur Aufarbeitung der SED-Diktatur, 2010), 7.

${ }^{20}$ According to Fricke, this includes victims of state oppression who were arrested because of "their political attitude, their belonging to a certain social class, or their political or religiously motivated opposition towards the Communists." See Karl Wilhelm Fricke, Politik und Justiz in der DDR: Zur Geschichte der politischen Verfolgung 1945-1968. Bericht und Dokumentation (Köln: Verlag Wissenschaft und Politik, 1990), 8; for the number of victims see Ansgar Borbe, Die Zahl der Opfer des SED-Regimes (Erfurt: LZT, 2010), 18.

${ }^{21}$ Gleinig and Kaminski, Übersicht über Beratungsangebote, 7-8.

22 Ibid. 
the...question of the legitimacy of the GDR (or the FRG or unification)."23 The communist oppressors' narratives have mostly been excluded from the public sphere. This raises a question as to whether, 30 years after reunification, the state can find a balanced approach to confronting the communist past in Germany.

This paper introduces an original approach to political apologies. It regards them as a stimulus for the kind of public discourse that promotes revelations and reinterpretations of past injustices. Adopting a discourse analysis approach, it considers politicians' apologies to be systems of social relations and practices that are intrinsically political. ${ }^{24}$ The paper will investigate the narratives of different entities, such as former GDR officials, informants, members of the successor parties to the communists, the media and press agencies, asking how, after German reunification, contemporary political elites have dealt with former GDR officials and the perpetrators of crimes. How do the victim groups and the public react to public apologies?

This paper will proceed as follows: After this introduction of the context (Section I), Section II will introduce the theoretical concept of the political apology. Section III will explain the choice between strategies of retribution and reconciliation in confronting past communist injustices. Finally, Section IV will highlight three case studies of political apologies in Germany after 1989. The concluding Section $\mathrm{V}$ will then discuss the paper's main findings.

\section{The Concept of the Political Apology}

According to the Oxford Dictionary, the word apology originates in the Greek word apologia, meaning "a speech in one's own defense." Apologies are characterized by three crucial elements: an acknowledgment of an offense or failure; a formal expression of regret; and a plea for forgiveness. ${ }^{25}$ Scholars distinguish between individual and political apologies. While individual apologies focus on the private relationships, political apologies transmit a "reconciliatory

23 Andrew H. Beattie, Playing Politics with History, The Bundestag Inquiries into East Germany (New York: Berghahn Books, 2008), 7. Italics in original.

${ }^{24}$ David Howard and Yannis Stavrakakis, "Introducing Discourse Theory and Political Analysis," in Discourse Theory and Political Analysis, ed. David R. Howarth et al. (Manchester: Manchester University Press, 2000), 1-39.

25 "Apology," in Oxford Dictionary of English, 3rd edition, ed. Angus Stevenson and Judy Pearsall (Oxford: Oxford University Press, 2010), 73. See also Carl D. Schneider, "What it Means to be Sorry: The Power of Apology in Mediation," Mediation Quarterly 17, No. 3 (Spring 2000): 265-280; see also Nicholas Tavuchis, Mea Culpa: A Sociology of Apology and Reconciliation (Stanford, CA: Stanford University Press, 1991). 
message" from the private sphere into the public national level or vice versa. ${ }^{26}$ A political apology can be expressed on behalf of a collective or an identity group and can address either an individual or a group. The ICTJ argues that apologies are a communicative act with greater normative moral impact than an ordinary act of speech because "apologies have value in themselves and can address both moral and physical harm." They "reflect a communal reckoning with crimes of the past" and they can help to prevent such events from ever happening again. ${ }^{27}$

Since the 1990s, against the backdrop of the third wave of democratization, we have observed a politicization of apology speeches across Europe. Scholars characterize public apologies as a speech act (hence the term "apology speech") and a symbolic political gesture of reconciliation that represents a logical stage in the advancement of a society. ${ }^{28}$ National apology speech has a special social and political import due to its official character and the claim that it represents the official state interpretation of past history.

The dialogue begins with a symbolic request by the perpetrators, collaborators or successors for forgiveness from an injured party. Perpetrators and victims are entangled in a shared difficult past, joining them in a "destiny community" for life. ${ }^{29} \mathrm{~A}$ public apology is a precarious request by the perpetrator to be forgiven and accepted into the currently dominant social order. It empowers the victim to decide if the perpetrator will in fact be forgiven and reintegrated into society. It requires a certain space or environment and a certain audience to transmit the moral message out into society. According to Daase, the following criteria determine the outcome of the reconciliation process (whether on the interpersonal or the national level): the credibility of the performer of the apology and their performance, and the intensity of remorse and the acknowledgment of victimhood that they show. ${ }^{30}$ The act of an apology is a reciprocal, dialogical process that requires a communicative encounter between the parties themselves or their representative identity groups. Consequently, this paper's position is that the engagement of perpetrators and victims in a broad public discourse raises

${ }^{26}$ Karina Strübbe, Politische Entschuldigungen: Theorie und Empirie des sprachlichen Handelns (Wiesbaden: Springer Fachmedien, 2017), 63-82.

27 Ruben Carranza, Cristián Correa, and Elena Naughton, More Than Words: Apologies as a Form of Reparation (New York: International Center for Transitional Justice, 2015), 1, https://www.ictj .org/sites/default/files/ICTJ-Report-Apologies-2015.pdf.

28 Daase, "Entschuldigung und Versöhnung," 43-49.

${ }^{29}$ Katharina Gajdukowa, "Opfer-Täter-Gesprächskreise nach dem Ende der DDR," Aus Politik und Zeitgeschichte, No. 41-42 (October 4, 2004): 23-28, here 24.

30 Daase, Engert, and Renner, "Introduction," 1-29. 
the probability that an apology will be accepted. This highlights the special role of the media as the transmitter of the "reconciliatory" message.

The ideal apology requires a confession of guilt from the wrongdoer, who is powerless in the situation and who must run the risk of not being forgiven by the victim and the public audience. The higher the public awareness of the acceptance by the victims to forgive or not to forgive, the higher is the impact of the apology speech on the broader society. Furthermore, the more there are of victims who express support for the repentant individual or group, the more likely and complete the perpetrator's reintegration into society will be. ${ }^{31}$

If reconciliation is to be more than a theoretical construct, it needs to have practical implications. Scholars consider reconciliation to be the ultimate normative purpose of Vergangenheitspolitik and transitional justice. ${ }^{32}$ They see it as a counterbalance to human rights abuses, which seeks to end long-term conflicts and overcome international or domestic divisions between perpetrators and victims in the wake of war or the collapse of a non-democratic regime. Lily Gardner-Feldman defines reconciliation as a process through which opponents of formerly ruling non-democratic regimes steer their relationship away from vengeance and "[from] bilateral enmity towards harmony and ideally, friendship." ${ }^{3}$ Especially in cases where nations are divided, such as Germany, Korea, Cyprus and Israel-Palestine, conflict and peace researchers observe a strong interdependency between the domestic and international politics of reconciliation. ${ }^{34}$

The vigor of the public discourse resulting from a political apology determines the quality and the effectiveness of the reconciliation process at the international and national level. In general, political speeches of apology are an instrument of reconciliation and are a precondition for its success. Apology speech is most often used on the international level, but it can appear on the national or sub-national level as well. Its impact on the process of reconciliation

31 Ibid.

32 The German term Vergangenheitspolitik jumped from the national to the international sphere in the comparative research of dictatorships after 1990. It is used as a synonym for "working through a troubled past," mostly by historians and political scientists. Meanwhile, the term transitional justice has arisen to describe the practices of war crimes tribunals, truth commissions, and restitution and rehabilitation processes. See Veit Straßner, "Vergangenheitspolitik, Transitional Justice und Versöhnung," in Handbuch Transitional Justice, ed. Anja Mihr, Gert Pickel, and Susanne Pickel (Wiesbaden: Springer VS, 2018), 201-233.

33 Gardner-Feldman, Germany's Foreign Policy, 2.

34 Goschler, "German Reunification," 133-134; see also Catherine Lu, Justice and Reconciliation in World Politics (Cambridge: Cambridge University Press, 2017), 38, doi: 10.1017/ CBO9781108329491. 
between perpetrator and victim groups and within a society as a whole can be measured.

Efforts at reconciliation and political apologies are complementary, in that they both imply moral agency and impact collective memory and identity in divided societies. Currently governing officials represent their identity groups, as do former government officials, leaders of victim and human rights organizations, and other collective actors. Their individual acts of contrition or forgiveness can have a multiplier effect on reconciliation in their societies. Their symbolic gestures provide insight into new moral standards among the elites as they face up to past crimes and their repercussions. Additionally, their gestures inform us about the perceptions of victims, perpetrators and collaborators about progress toward reconciliation. The discourse involves competing, contested historical narratives about past injustices and crimes and reflects the feedback the participants in the dialogue are receiving from the local level.

In the context of historical justice, reconciliation means the end of one dominant, unilateral narrative about the past. Moreover, reconciliation is a recognition "that there are (at least) two narratives" about the problematic past. ${ }^{35} \mathrm{In}$ eastern Germany's particular post-communist politics of the past, ${ }^{36}$ i.e., in dealing with the legacy of the GDR communist dictatorship, "reconciliation" means finding a balance between the contested narratives of the old communist elites, collaborators, and representatives of the Communists' successor party on the one hand and former dissidents and victim and civil rights groups on the other. A few publications on reconciliation policy in eastern Germany focus on the "perpetrator-victim mediation" process that took place in small groups, mostly in the framework of church initiatives at the beginning of the $1990 \mathrm{~s} .{ }^{37}$

In the aftermath of dictatorship, open wounds often remain between perpetrators and collaborators with the former state on the one hand and victims and their relatives who suffered from their injustices on the other. In the so-called "asymmetric relationships" that follow dictatorships, members of marginalized minority groups that were the most frequent victims of political harassment, persecution, imprisonment and re-education transfer their antagonisms to the

35 Daase, Enger and Renner, "Introduction," 1-29.

36 The Anglo-Saxon term "politics of the past" describes the function of history research in reconstructing perceptions of the past and drawing lessons from it in order to mobilize intellectual discourse and social movements. See John Torpey, Politics and the Past: On Repairing Historical Injustices (Lanham, MD: Rowman and Littlefield, 2003); and Nikolay E. Koposov, Memory Laws, Memory Wars: The Politics of the Past in Europe and Russia (Cambridge: Cambridge University Press, 2018). doi: 10.1017/9781108304047.

37 Gajdukowa, “Opfer-Täter-Gesprächskreise,” 23-28. 
next generation. This leads to a vicious circle of revenge and mistrust, which ideally should be prevented and transformed into a more positive relationship.

Research on political apology speech as an instrument for political reconciliation is quite a new field that is still being defined. Furthermore, the tools for producing comparative case studies are lacking. The literature that emerged after 1990 coincided with an increase in the number of societies that were undergoing transition. Because of the very short time span in which the studies were performed, assessments of the efficacy of political apologies in promoting social reconciliation are conflicting. Obstacles to the sharing of knowledge and theoretical concepts among international and domestic researchers resulted from the heterogeneous cultural and linguistic landscape of Eastern Europe.

German historians and political scientists in particular have reservations about applying highly moralized discourse to political reconciliation. This attitude reflects the different etymological and cultural origins of the word "reconciliation." The term originates in the Latin word reconciliare, which means either "to restore friendly relations" (in German, wiederherstellen) or "bring together again" (wieder zusammenbringen), ${ }^{38}$ both of which have rather positive connotations. On the other hand, the German word Versöhnung has the somewhat negative connotation of seeking retributive justice "to atone for" or "to expiate" (sühnen) past sins. ${ }^{39}$ The German term Aussöhnung refers to one-sided compensation for guilty acts. It contrasts with Versöhnung, which implies a shift in power from perpetrators to victims. Some experts criticize reconciliation as too "soft" an approach and as an attempt by former functionaries to draw a line with the past (Schlussstrichmentalität) ${ }^{40}$ or as an "empty compensation ritual" which recalls the very common German phrase "to forgive and forget" (Vergeben und Vergessen). An academic debate about "reconciliation kitsch" (Versöhnungskitsch), ongoing since 1994, is an example of the negative aspects of the term reconciliation as it has been used to avoid the normative dictate "to work through the past" in the reunified Germany. ${ }^{41}$

The discussion above illustrates the strong doubts that exist in Germany about the value of a political apology speech. It helps to explain the general lack

\footnotetext{
38 "Reconcile," in Oxford Dictionary of English, https://en.oxforddictionaries.com/definition /reconcile.

39 “Versöhnung," in Ethymologisches Wörterbuch des Deutschen, ed. Wolfgang Pfeifer, https://www .dwds.de/wb/Vers\%c3\%b6hnung. See also Michael O. Hardimon, Hegel's Social Philosophy: The Project of Reconciliation (Cambridge: Cambridge University Press, 2002), 85.

40 See Hans Henning Hahn, Heidi Hein-Kircher, and Anna Kochanowska-Nieborak, eds., Erinnerungskultur und Versöhnungskitsch (Marburg: Herder-Institut Verlag, 2008).

41 Hammerstein and Trappe, "Aufarbeitung der Diktatur," 17.
} 
of initiatives on the national and grassroots levels for reconciliation after the crimes of communism. This lack indicates the continued distancing of the communist heritage from present-day politics, combined with a culture of silence among former GDR officials and their exclusion from the public discourse. It demonstrates a persisting failure of the German government to take responsibility for the divided narratives of the shared communist past and to include the divided social identity groups and their antagonistic historical narratives into a shared public discourse as an unavoidable and important part of Germany's national heritage. This one-sided memory building process has produced a sentiment of heteronomy and further deepened existing social division in eastern German society.

The manner in which the East German state was subsumed into Federal Republic of Germany (FRG) and its norms after 1989, and the manner in which the old eastern elites were replaced, determined the opportunity for coming to terms with the past in the post-transitional period. Most initiatives for measures of transitional justice originated in the West and were based on decades of experience in dealing with human rights crimes under the Nazi regime. ${ }^{42}$ The double weight of fascist and communist dictatorship, and the "accession" of the GDR to the FRG, allowed eastern German society to avoid self-critical discourse about its past. Public discourse since 1989 has predominantly focused on the victims, instead of on the former GDR elites who were quickly and effectively delegitimized and disempowered. ${ }^{43}$ That the elite was stripped of its power does not mean that the human beings they ruled, who include more than 200,000 political victims as well as more than 2.3 million members of the Communist Party as political collaborators of the oppressing regime, disappeared. Their memories of the time before 1989 were banished from public into the communicative sphere of family talk. New studies demonstrate the negative impact the persisting inter-generational transmission of old antagonistic stereotypes still has on eastern German society. ${ }^{44}$

Additionally, there was and still is no independent media in eastern Germany that is interested in promoting a discourse of public reconciliation after 1990 .

42 Goschler, "German Reunification," 125.

43 The victim-centered discourse in Europe is discussed in Jürgen Gerhards, Lars Breuer, and Anna Delius, Kollektive Erinnerungen der europäischen Bürger im Kontext von Transnationalisierungsprozessen. Deutschland, Großbritannien, Polen und Spanien im Vergleich (Wiesbaden: Springer VS, 2017), 205.

44 See Pumla Gobodo-Madikizela, ed., Breaking Intergenerational Cycles of Repetition: A Global Dialogue on Historical Trauma and Memory (Opladen: Barbara Budrich Publishers, 2016). 
In the middle of the 1990s, the vivid desire to confront past communist crimes and the opportunity to increase social cohesion between former political opponents changed into an atmosphere of disillusionment and distrust toward the new authorities. For instance, the anti-communist, conservative-led "red socks" campaign of 1994 attempted to exploit the social and political internal divisions in eastern Germany, which still exist under the surface. It symbolized the interference of western politicians and elites into eastern German local politics and the continuation of former Cold War enemy stereotypes after reunification. In that campaign, Christian Democrats condemned the minority government of the Green Party and the Social Democrats (1994-1998) in Saxony-Anhalt, which enjoyed the backing of the PDS. The campaign instrumentalized political symbols of the communist era, such as the "red handshake" that merged the Social Democrats into the communist SED in 1946. It was intended to frighten the German population with the specter of a resurrection of the Communists and deepened antagonistic stereotypes from the Cold War. ${ }^{45}$

Taking an innovative research approach, this paper will explore whether political apology speech has led (ideally) to interpersonal and national reconciliation and if it did (at least) actually stimulate public discourse about past communist injustices in post-1989 eastern Germany. The selected case studies give insight into the views of left-wing politicians having a certain ideological or personal continuity with the former GDR regime and the three different types of political apologies they have expressed. The cases differ in their temporal situation and the personal closeness of the politicians to the injustices committed under the East German communist regime. They give information about the effects of apologies on advancing social reconciliation and mobilizing discursive strategies.

The first speech was given in 1994 by Dietmar Keller, a former GDR official who epitomizes the old nomenklatura of the GDR. Applying Karl Jaspers' categories of German guilt, ${ }^{46}$ Keller is morally responsible for past GDR injustices as a member of the leading political monopoly SED and as the minister in charge

45 Juliet Roper, Christina Holtz-Bacha, and Gianpietro Mazzoleni, The Politics of Representation. Election Campaigning and Proportional Representation (New York: Peter Lang, 2004), 77-99, here 93.

46 Jaspers differentiates four dimensions of guilt: (1) criminal guilt based on an objective, individual violation of existing law, (2) political guilt of public entities that have responsibility for state crimes, (3) moral guilt borne by an individual as part of an identity group of a nation, culture, religion or ethnicity, (4) metaphysical guilt that includes everyone who does not resist at the moment an injustice is done. See Karl Jaspers, The Question of German Guilt, transl. by E. B. Ashton (New York: Dial Press, 1947). 
of cultural affairs. I argue that perpetrators, causal agents and representatives of culpable identity groups need to address all the various categories of guilt during a national apology speech in order to increase its impact on the response level. To be an effective instrument for reconciliation, an apology speech should recognize the different levels and nature of guilt. Hence, the more precisely and immediately a confession of guilt or remorse is directed toward the victims or the group representing the victims, the higher is the probability the apology will be accepted.

The second apology speech, given in 2014, was made by a representative of Die Linke, a successor party of the communist SED and the PDS: Bodo Ramelow, the Minister President of the federal state of Thuringia in eastern Germany. His speech admits to his party's ideological continuity with the GDR regime, but it also represents the views of a person who was not affected by communist crimes and who was educated under democratic norms and the rule of law in the former West Germany.

The third case is that of a former unofficial Stasi informant, Frank Kuschel. His speeches were given in 2006 and in 2012 before the Thuringian Parliament. Kuschel is one of more than 189,000 unofficial collaborators like him. ${ }^{47}$

\section{Strategies for Confronting the East German Past after 1989}

An apology, particularly a public one, is a necessary if not a sufficient condition for reconciliation. 48

East Germany was ruled by the one-party communist dictatorship of the SED between 1948 and 1989. Beginning in the spring of 1989, a lively citizen and opposition movement called for a change of government and the peaceful transition of the GDR to democracy. This transition was realized in the short historical time frame of one and a half years, between spring 1989 and the end of 1990, by which time all aspects of the political transition of eastern Germany were complete. Normative legal, judicial, and democratic standards and values were transferred from the former West Germany to a reunified state that included all of the former East Germany.

47 Helmut Müller-Enbergs, ed., Inoffizielle Mitarbeiter des Ministeriums für Staatssicherheit, Vol. 1: Richtlinien und Durchführungsbestimmungen (Berlin: Ch. Links Verlag, 2001), 4.

48 Juan Espindola, Transitional Justice after German Reunification (Cambridge: Cambridge University Press, 2015), 217, doi: 10.1017/CBO9781316014851. 
Political scientist Juan Espindola described the immediate post-transition period of reunified Germany as follows: "Post-unification confrontation of the East German communist past...was not only about justice, truth, reconciliation... but also about power and ideology." 49 Jennifer Yoder has argued that Germany put in place a well-defined truth-seeking and memory-building process with regard to its contested past, but failed to continue its politics of reconciliation after the first years of the 1990s. ${ }^{50}$ New right-wing movements emerged after German reunification that were fostered by an ongoing division of German identity based on unresolved issues in the communist past and narratives that have been passed on unopposed to the next generation. ${ }^{51}$ The Alternative for Germany, a right-wing party with a neo-fascist ideology, received the most votes in the German federal parliamentary elections of 2017 in the eastern German state of Saxony, as well as receiving high percentages in all other eastern German states. Its electoral success raises questions about the fading of the "reconciliatory environment" and the continued existence of divisions within eastern German society. Observing political reconciliation in post-communist Germany almost than 30 years after reunification, Henning Pietzsch (born 1962 in Zeitz, Halle, East Germany, and a historian and civil rights activist of a church group opposed to the Communists) states that there is hardly any willingness for collective national reconciliation in eastern Germany, whether on side of the perpetrators or the victims. Instead, one finds "mutual refusal, resentment and bitterness within their identity roles," which "continues as in the time of the Cold War." 52

A government poll conducted in 2015 on the occasion of the twenty-fifth anniversary of German reunification gave more detailed insight into the reconciliatory environment and the (un)willingness of the local eastern German population to seek and offer forgiveness. Approximately 40 percent of those questioned who were over 45 years of age mentioned "dialogue and reconciliation" as their most-desired aim of government policy with regard to the memory

49 Ibid., 68.

50 Jennifer A. Yoder, "Truth without Reconciliation: An Appraisal of the Enquete Commission on the SED Dictatorship in Germany," German Politics 8, No. 3 (2007): 59-80, doi: 10.1080/09644009908404568.

51 Jürgen Danyel, "Spätfolgen? Der ostdeutsche Rechtsextremismus als Hypothek der DDR-Vergangenheitspolitik und Erinnerungskultur," in Fremde und Fremd-Sein in der DDR. Zu historischen Ursachen der Fremdenfeindlichkeit in Ostdeutschland, ed. Jan C. Behrends, Thomas Lindenberger, and Patrice G. Poutrus (Berlin: Metropol, 2003), 23-101, here 23-24.

52 Henning Pietzsch, "Versöhnung - Politischer Auftrag oder Private Angelegenheit," in Thüringen: Braucht das Land Versöhnung? Kritisches Jahrbuch der Philosophie 17, ed. Martin O'Malley et al. (Würzburg: Königshausen \& Neumann, 2017), 87-102. 
of the East German regime, followed by rehabilitation (29\%) and education in democratic values (29\%). At least one third of people over 45 , most of whom were educated under communism, and a third of the transitional generation of 25- to 34-year-olds, welcomed a balanced historical approach instead of a one-sided, victim-oriented way of dealing with past communist crimes. ${ }^{53}$ In contrast, 18 - to 24-year-olds, the first generation born after reunification, showed less interest in a balanced, "moderate" approach to the communist past. These statistics confirm international observations that reconciliation policies and practices are mainly of interest to the generations that experienced trauma and that the willingness to reconcile decreases as people's temporal distance from past injustice increases. ${ }^{54}$ Some scholars criticize the calls for a balanced approach as a revisionist movement, intent on closing the books on past communist crimes (Schlussstrichmentalität)..$^{55}$ More optimistic scholars interpret them as opening a historical window, an opportunity to appreciate others' perspectives, and a chance to stimulate a new public discourse. This new discourse would include the perspective of both young scholars and non-affected generations raised under the new democracy as well as the "internal" perspective of the generation that lived under the GDR dictatorship.

The rapid dissolution of the East German state and its submission to West German legal norms and standards won out over the desires of some civil rights activists and reform-oriented elites who advocated a "soft" transformation with a consensual approach. The prerogative of interpreting the communist and fascist past was arrogated to an anti-totalitarian consensus and was the ideological starting point for the unified democratic nation. ${ }^{56}$ With some justification, Germany became a role model for Eastern Europe due to its multiplicity of legal, moral and historical achievements in working through the past. ${ }^{57}$ Indeed, the broad range of retributive and non-retributive measures of transitional justice, which included trials, purges, history commissions, and the creation in 1998 of

53 Heinrich Best et al., Politische Kultur im Freistaat Thüringen. Thüringen im 25. Jahr der deutschen Einheit (Jena: Institut für Soziologie, Friedrich-Schiller-Universität Jena, 2015), 56-57 and Figure A79, https://www.thueringen.de/mam/th1/tsk/thueringen-monitor_2015/thuringen-monitor 2015.pdf.

54 The Asan Institute for Policy Studies, "Asan Poll: Survey on South Korean Perceptions of Transitional Justice in Post-Unified Korea," in Transitional Justice in Unified Korea, ed. Baek Buhm-Suk and Ruti G. Teitel (New York: Palgrave Macmillan, 2015), 247-252, here 249.

55 Ibid., 56.

56 Eckard Jesse, ed., Totalitarismus im 20. Jahrhundert: eine Bilanz der internationalen Forschung (Baden-Baden: Nomos Verlag-Gesellschaft, 1999).

57 Lavinia Stan and Nadya Nedelsky, eds., Post-Communist Transitional Justice: Lessons from Twenty-Five Years of Experience (New York: Cambridge University Press, 2015). 
an entire governmental agency dedicated to working through the legacy of the SED dictatorship, was an outstanding example to follow.

But who were the victims, who were the perpetrators and how can we categorize the crimes?

Based on the human rights norms of the United Nations, International Covenant on Civil and Political Rights and International Covenant on Economic, Social and Cultural Rights, which the German Democratic Republic signed and ratified in 1973, most of the GDR's violations of human rights can be classified as crimes against life, health, individual liberty, and property, and political persecution of opponents. ${ }^{58}$ In the years from 1948 to 1989, between 180,000 and 250,000 people were arrested on political grounds in the GDR. ${ }^{59}$ According to Ansgar Borbe, about one million people were directly or indirectly affected by state violations and abuses of human rights during the 40 years of communist rule in East Germany. ${ }^{60}$ Approximately 42,000 politically motivated violations of the human rights of GDR citizens have been documented by the Federal Documentation Center in Salzgitter since 1961. ${ }^{61}$ The historian Klaus Schröder claims that the dimensions and intensity of the crimes committed by communist regimes are different from those committed by the Nazi dictatorship, but in general, the infiltration of society and the psychological indoctrination in daily life under the repressive communist system of state security, along with state control over the media, economy, education and the mobilization of population by mass organizations, is in fact comparable. 62

\section{Retributive Justice}

According to Constantin Goschler, a preliminary investigation following German reunification identified 100,000 suspects involved in killings at the East German border, voter fraud, perversion of justice, denunciations, atrocities by the secret police, mistreatment of captives, doping of athletes, abuse of authority, corruption and other economic offenses, and espionage.$^{63}$ Eventually only

58 Ansgar Borbe, Die Zahl der Opfer des SED-Regimes (Erfurt: Landeszentrale für politische Bildung Thüringen, 2010), 10.

59 Ibid., 17.

60 Ibid., 15.

61 Hubertus Knabe, Die Täter sind unter uns. Über das Schönreden der SED-Diktatur (Berlin: Propyläen-Verlag, 2007), 90.

62 Klaus Schroeder, Der SED-Staat. Geschichte und Strukturen der DDR (München: Hanser Verlag, 1998).

63 Goschler, "German Reunification," 126. 
40 defendants received a prison sentence (0.04 percent of those suspected). Only a few high-ranking party officers of the SED and of the Ministry for State Security (Stasi) were sentenced to prison for the destruction of dissidents' lives by denunciation, political imprisonment, persecution and psychological repression in re-education camps. ${ }^{64}$ Of course, many suspects were not punished at all because their individual wrongdoing could not be proven. This was obviously disappointing for victims and former dissidents.

One striking example of the inability to punish a political culprit is the case of the SED General Secretary Erich Honecker, who escaped sentencing thanks to his ill health. Honecker certainly never apologized to his victims. During the Politburo Trials, held between 1995 and 2000, ${ }^{65}$ main regime collaborators such as Egon Krenz and Günter Schabowski were sentenced to no more than four years in prison. The biggest obstacle to obtaining a conviction was the principle nulla poena sine lege (no punishment without law). As most of the accused's acts did not contravene either GDR or FRG law, obtaining a conviction was difficult. The prosecutions for human rights abuses evoked long-running trials. ${ }^{66}$

Apart from the GDR political authorities and party members, the officers of the Stasi were the main perpetrators of state repression in the GDR. They were most responsible according to categories of political guilt identified by Jaspers, with their denunciations and spying on any hint of political opposition. According to statistics published by the Federal Commission for Stasi Records (BStU), the State Security counted 189,000 unofficial collaborators in $1989 .{ }^{67}$ In 1989 , about 17 million people were living in the GDR, ${ }^{68}$ yielding a ratio of one informer for every 89 GDR citizens. ${ }^{69}$ After reunification, about 1,500 former Stasi officials were absorbed into the public service in Germany. This not only caused mistrust of the new authorities but also gave an impression of selective prosecution of collaborators that deepened the internal divisions in German society. The BStU admits that retributive justice in reunified Germany was "unsuccessful,"

64 Ibid., 123.

65 The Politburo was the highest central organ of the SED Party. Through it, the GDR elite influenced all the main political, economic and social sectors. It consisted of 21 senior members.

66 Neil J. Kritz, ed., Transitional Justice. How Emerging Democracies Reckon with Former Regimes, Vol. 2: Country Studies (Washington: USIP Press, 1995), 642.

67 Müller-Enbergs, Inoffizielle Mitarbeiter, 4.

68 Ansgar Borbe, Die Zahl der Opfer des SED-Regimes (Erfurt: Landeszentrale für politische Bildung Thüringen, 2010), 8.

69 “Inoffizieller Mitarbeiter (IM)," Der Bundesbeauftragte für die Unterlagen des Staatssicherheitsdienstes der ehemaligen Deutschen Demokratischen Republik, https://www.bstu.bund.de /SharedDocs/Glossareintraege/DE/I/ inoffizieller-mitarbeiter.html?nn=5976488. 
in that "through the year 2000, only 87 Stasi collaborators could be punished." 70 In 1991, a lustration law paved the way to removing former communist government officials from the public sector in the former East Germany. Consequently, civil servants in key educational institutions, public offices, and courts were identified as collaborators and replaced. For example, in Saxony alone nearly 13.400 teachers were suspended from their posts for collaboration with the former communist regime. ${ }^{71}$

In summary, there were a variety of tools of transitional justice, most of which failed to satisfy the victims' need for restoration of their dignity.

\section{The Politics of Reconciliation}

Due to the limited capability of the justice system to prosecute those responsible for communist crimes, other non-retributive measures such as the work of the parliamentary history commissions between 1992 and 1998 and laws on the restitution of property rights and rehabilitation of victims became important. By 1992, some 1.1 million restitution claims had been filed involving over half the land area of the former GDR. ${ }^{72}$ A remarkable practice was the possibility for individuals to view the information gathered on them by the GDR state security. The objective was to allow personal encounters with past suffering. Since 1989, the Stasi files have been archived in response to continuing protests and the demands of opposition groups and civil rights activists. The BStU was founded in 1991 and since then has collected more than 69 million individual security files, which have been transferred to the national archives and made accessible to their subjects, to the public at large, and to scholars. ${ }^{73}$ From a historical point of view, the accessible research material will help future generations to reconstruct past crimes based on first-hand sources and to work through a complex history.

Due to shifting power relationships and the exclusion of former elites from the public sphere, a truly cathartic encounter between victims and perpetrators was impossible in eastern Germany. Shortly after the transition in the 1990s, mediated encounters between victims and perpetrators did take place in few

\footnotetext{
Ibid.

71 Mary Albon, "Report to Democracy and Decommunization: Disqualification Measures in Eastern and Central Europe and the former Soviet Union" (Conference Paper by the Project on Justice in Times of Transition, New York, November 14-15, 1993).

72 Kritz, Transitional Justice, 644.

73 Ralf Wüstenberg, Die politische Dimension der Versöhnung. Eine theologische Studie zum Umgang mit Schuld nach den Systemumbrüchen in Südafrika und Deutschland (Gütersloh: Gütersloher Verlagshaus, 2014), 309.
} 
cases, but only on the local level, between individuals or in small-group settings like the House at Check Point Charlie in Berlin. ${ }^{74}$ Contemporary media like Der Spiegel labeled the post-1989 environment as a "witch-hunt" between perpetrator and victim groups. Former Stasi officers and their collaborators fled to obscurity in West Germany or abroad. ${ }^{75}$ In some cases, harassment of identifiable perpetrators resulted in their early death or suicide. ${ }^{76}$ According to Jan Behrends, feelings of a loss of "self-determination" and of "foreign" domination were strong in the collective perception and inter-generational memory of the East German population. This created a fertile basis on which radical neo-fascist groups could increase after $1990 .{ }^{77}$

\section{Political Apology Speeches in post-1989 Germany}

\section{Dietmar Keller: "No Reconciliation without Truth - No Truth without Reconciliation"}

Returning to Dietmar Keller's speech of political apology, I argue that his 1994 statement was a rare, outstanding example of a gesture of reconciliation at the early stage of transition. Keller fulfilled Daase's main criteria for a fruitful apology. He confronted past communist crimes critically, he acknowledged the repressive structure of the GDR dictatorship, and he took personal responsibility for his collaboration with the repressive regime. Keller showed deep remorse towards his victims and confessed his guilt. His apology gave him back his dignity and created the preconditions for his acceptance by former victims and opposition groups, as well as by the political elites in the then newly-elected Bundestag and the new, democratic society of the unified Germany.

The parliamentary Enquête Commission (1991-1994), formed to work through the troubled communist past, provided a historic impetus and constituted a unique time and space for encounters between former GDR officials like Keller and their opponents, and for reconciliation. ${ }^{78}$ The protected environment of the Commission's hearings and its historic truth-seeking processes exposed

74 Gajdukowa, “Opfer-Täter-Gesprächskreise," 23-28.

75 “Neugier Aneinander," Der Spiegel, March 9, 1992, http://www.spiegel.de/spiegel/print /d-13687423.html.

76 Pietzsch, "Versöhnung - Politischer Auftrag oder Private Angelegenheit," 90.

77 Jürgen Danyel, Spätfolgen? (Berlin: Metropol, 2003), 24.

78 See Ralf K. Wüstenberg, The Political Dimension of Reconciliation: A Theological Analysis of Ways of Dealing with Guilt during the Transition to Democracy in South Africa and (East) Germany (Grand Rapids, MI: Eerdmans, 2009). 
the repressive structure of the GDR system and acknowledged the pain of its victims. The Commission created conditions for symbolic steps toward reconciliation. The conciliatory moment and the dialogical encounters of perpetrators and victims took place in (semi)public hearings.

Keller's speech was met with approbation from all factions of the Bundestag, including former civil rights activists and clergy like Rainer Eppelmann and Gerd Poppe, and was regarded as an inclusive appeal for forgiveness. The price for acceptance of his apology was his acknowledgment of the new democratic norms and his admission of former injustices. He had to distance himself from the crimes committed by the regime he had served. At the same time he risked being excluded from his own identity group of former party members and regime collaborators.

Keller's speech of apology lacked any support from his PDS party colleagues and contradicted the consensus of the former elites. Fellow members of the post-communist PDS party criticized his speech harshly, but nevertheless it did provoke an internal dispute within the PDS over the proper interpretation of the communist past. Keller distanced himself from the PDS and resigned from it in $2002 .{ }^{79}$ His resignation substantiates the argument that his apology was an individual decision to heal himself of his guilt feelings, rather than a sentiment that was widely accepted and shared by left-wing politicians. At the same time, his speech demonstrated the limits of such political apologies. The positive response toward him from the former opposition did not mean they collectively forgave and accepted his fellow former communists, nor that they absolved them of their individual responsibility for the communist past. If a political apology is to have a multiplier effect on the identity group of the one who offers it, there must be a common sense of the identity group's mission that person is transmitting into the public sphere. That was the case with Minister President Ramelow, below, which proves the hypothesis.

Keller's symbolic gesture did not fulfill the necessary temporal and spatial relationship to the injustices and to the political transition from the GDR to the unified Germany. As the documentary film What Became of the SED?, broadcast in 2016 by ARD/MDR, stated, "for some of the party of the left, this apology came too early, for most of the victims it came too late." 80 The closed-door forum

79 Dietmar Keller, Zwischen den Stühlen (Berlin: Dietz, 1993); see also Ralf K. Wüstenberg, Aufarbeitung oder Versöhnung? Ein Vergleich der Vergangenheitspolitik in Deutschland und Südafrika (Potsdam: Brandenburgische Landeszentrale für politische Bildung, 2008), 169.

80 Jan Lorenzen, "Was wurde aus der SED?" in Filmreihe 'Geschichte im Ersten' (ARD/ MDR), November 21, 2016, https://www.mdr.de/tv/programm/sendung716404.html. 
of the apology prevented a broad public response from victim and opposition groups and the broader population of eastern Germany. Some former dissidents had become members of the Christian Democrats and the newly-formed Green Party, such as Gerd Poppe (Green Party) and Rainer Eppelmann (CDU). Their positive reception of Keller's apology in the Bundestag in Bonn produced some effects on the inter-personal level between members of those parties and the PDS. Nevertheless, the final demand of Keller's speech, that there would be "no truth without reconciliation," 81 failed to win wide public acceptance due to the political realities and the existing power relations of the time. This result reflected the dilemma posed by the struggle for control of the master narrative in Germany after 1989. While the new elites demanded complete authority over the interpretation of the past as a precondition for reconciliation, the perpetrators and collaborators sought a balanced approach that included their perspective. The latter position stood in opposition to the priorities of the victims who were newly empowered in post-1989 Germany.

In conclusion, Keller's speech can be categorized as an individual's speech of political apology. The lack of a public audience, the absence of media coverage, and especially Keller's lack of authority to speak on behalf of his party colleagues and perpetrator groups all decreased the multiplier effect of his apology. That he sought forgiveness for his past crimes gave him credibility within the Bundestag and allowed him individually to be accepted by opposition and victim groups. However, it excluded him from his former colleagues who suffered from their criminal entanglements. We have to state that Keller's speech of apology did not resonate much in eastern German society. But his speech did have some positive effect on semi-public and internal discourse within the political left and among former GDR officials, ${ }^{82}$ by encouraging the opening of debate about their own individual relationships with their communist past and the legacy of the GDR dictatorship.

\section{Bodo Ramelow: "Reconciling Instead of Dividing Societies"}

In autumn 2014, twenty-five years after German reunification, Die Linke (the Left Party) gained power in the eastern German state of Thuringia for the first time. Bodo Ramelow became the state's Minister President, and introduced

81 Deutscher Bundestag, ed., Enquete-Kommission, 815.

82 I categorize the debate sparked by Keller's speech as semi-public because the internal dispute was documented in Keller's book, Zwischen den Stühlen (Berlin: Dietz 1993). 
a moral paradigm shift in the official treatment of past communist crimes. His speech of apology was an outstanding moment in post-1989 German history, and was a symbolic political acknowledgment of moral agency that enhanced reconciliation between former oppressors and dissidents.

A short explanation of the historical background will clarify the discursive paradigm shift with regard to the communist past. Die Linke was founded in 2007 as a merger of the Electoral Alternative for Labor and Social Justice (WASG) and the PDS. During the 1990s, the PDS was allowed to campaign and operate in all of the former East German states. However, it was constantly under suspicion of harboring former Stasi officials and GDR collaborators. ${ }^{83}$ Following state parliamentary elections in October 2014, Die Linke formed a coalition with the Green Party and the Social Democrats. Their coalition had 86 representatives, 28 of whom belonged to Die Linke. In November of the same year, the daily Handelsblatt announced that seven delegates from Die Linke in the Thuringian Parliament had been Stasi officers, members of the former East German National People's Army (Nationale Volksarmee, NVA), or border troops. ${ }^{84}$ The population of eastern Germany, especially victim groups, erupted in protest. Nevertheless, only one month later, for the first time in regional history, Die Linke took charge of the state government. The day before Ramelow's inauguration as Minister President, 1,500 citizens, some of whom had belonged to former opposition and victim groups and had participated in the civil rights movement during the upheaval of 1989, protested in the streets, shouting Stasi raus! (Stasi get out!). ${ }^{85}$ Against this historical background, Ramelow's inaugural speech drew special attention.

In his speech, Ramelow apologized to the victims of communism before the state parliament in Erfurt. He singled out his friend Andreas Möller, a victim and political prisoner under the communist dictatorship, and asked Möller to grant him forgiveness for the injustices committed by the GDR in the name of all his fellow victims. Quoting Federal President Johannes Rau of the Social Democratic Party (SPD) (in office 1994-2004), Ramelow pleaded for "reconciling instead of dividing society." He called for a process of mutual dialogue, respect and trust-building, to include both perpetrators and victim groups. His speech

83 Dan Hough, The Fall and Rise of the PDS in Eastern Germany (Birmingham: The University of Birmingham Press, 2001).

84 Laura Waßermann, "Wieviel DDR steckt in den Thüringer Linken?" Handelsblatt, November 3, 2014.

85 Merle Schmalenbach, “Bodo Ramelow. Der Versöhner," Cicero, December 5, 2014, https://www .cicero.de/innenpolitik/bodo-ramelow-der-wogenglaetter/58591. 
symbolized a break with the prior official, one-sided, victim-centered approach to the past crimes of the GDR's communist regime. Instead, Ramelow urged the former GDR elites to enter into a dialogue. "We need to go down this path together when working through the past!" he said. ${ }^{86}$

Ramelow then turned his attention completely towards the victims and acknowledged their protests in 1989 to be a historic moment for Germany. The immediate target of his apology, Andreas Möller, was seated in the Landtag before him. From the age of 19, Möller was a political prisoner between 1963 and 1965 in Waldheim (Gera, East Germany) because he had tried to help the pregnant fiancée of a friend to flee the East. In 1965 he was ransomed by the West German government and emigrated to the West. After reunification, he returned home to eastern Germany. He was a cofounder of the conservative magazine Bild in Thüringen. Working as a journalist, Möller has been friend with Ramelow for more than ten years. Möller is just one of tens of thousands of victims of communist state injustice. In his speech, Ramelow, who grew up in West Germany and moved to Thuringia after 1990, distanced himself personally from communist crimes but still showed deep remorse for them. His biographical distance from the crimes increased his credibility in the eyes of the victims. In an interview with the German Press Agency following Ramelow's speech, Möller stressed that the apology had a healing effect ("a catharsis") on him and was gratifying to him even half a century after the injustices inflicted upon him. ${ }^{87}$ He pointed out the symbolism of Ramelow's plea for forgiveness, which he felt addressed all his "friends" who "did not receive an apology from anyone." 88

In contrast to Dietmar Keller in the previous case, Ramelow enjoyed the support of the leading members of Die Linke. This gave him the authority to speak not only as an individual but also as a representative of his party colleagues and former GDR elites with close ideological links to the Left Party. Only a few weeks before the 2014 election the board of Die Linke made a statement in which they denounced the GDR state as a "political despotism," which "could replace

86 Bodo Ramelow, “Die Rede des Ministerpräsidenten von Thüringen im Wortlaut,” Der Tagesspiegel, December 5, 2014, http://www.tagesspiegel.de/politik/bodo-ramelow-die-rede-des-ministerpraesidenten-von-thueringen-im-wortlaut/11082066.html.

87 Florian Kain, "Nach Entschuldigung im Landtag. DAS denkt das Stasi-Opfer über Ramelows Auftritt. Ministerpräsident sprach Ex-Bild-Reporter Andreas Möller auf DDR-Verbrechen an,” Bild, December 5, 2014.

88 German Press Agency, "Ramelow entschuldigt sich bei SED-Opfern," Thüringische Landeszeitung, December 5, 2014. 
law and justice any time, and in which tens of thousands of biographies were refracted through state injustice and destroyed." 89

The public response from victim and opposition groups, and also from both conservative and left-wing media, appeared on the local and the international level. It had a great impact on the interpretation of the communist past in Germany. ${ }^{90}$ The response revealed the open wounds of the former GDR opposition, which were still painful almost 30 years after reunification. The leading German newspapers and magazines ran highly emotional articles about the new moral stance of the political leadership in Thuringia. ${ }^{91}$ For instance, the right-wing magazine Cicero dubbed Ramelow the "Reconciliator" (Der Versöhner). ${ }^{92}$ Ramelow's apology met all the criteria of Daase's categorization of reconciliation, and his inter-personal gesture of reconciliation toward Möller had a stimulating effect on public discourse. However, his speech did not result in a multiplier effect of stimulating forgiveness among the victim groups in eastern German society towards their former oppressors.

On the contrary, victim organizations and civil rights activists from the former GDR opposition movement reacted with great mistrust. Joachim Gauck, Germany's Federal President from 2012 to 2017, broke a promise he had made to remain neutral. He harshly criticized the entangled power relations between former GDR elites and new democratic parties. The chairman of one anti-communist victim group, Rainer Wagner, rejected Ramelow's rehabilitation gesture as a "defeat of the 1990's democratization movements and an insult to the victims." 93 The cofounder of the Social Democrats in the GDR, Stephan Hilsberg, even considered Ramelow's new morality as a contribution to the division of society, instead of its reconciliation. ${ }^{94}$ The director of the memorial to political prisoners in Berlin-Hohenschönhausen voiced the widespread concern of victim

89 German Press Agency, "Linke bekräftigt Entschuldigung für DDR-Unrecht," November 11, 2014, http://www.t-online.de/nachrichten/deutschland/parteien/id_71717130/linke-bekraeftigt-entschuldigung-fuer-ddr-unrecht.html.

90 Justin Huggler, "German Far-Left Party takes State Parliament," The Telegraph, December 5, 2014, http://www.telegraph.co.uk/news/worldnews/europe/germany/11276037/German-far -Left-party-takes-state-parliament.html.

91 “Ramelow bittet SED-Opfer um Entschuldigung," Frankfurter Allgemeine Zeitung, December 5, 2014, http://www.faz.net/aktuell/politik/inland/ministerpraesident-bodo-ramelow-entschuldigt-sich-bei-sed-opfer-13304142.html.

92 Schmalenbach, "Bodo Ramelow. Der Versöhner."

93 "Ramelow bittet SED-Opfer um Entschuldigung."

94 See interview at Deutschlandfunk "Reaktionen auf Ramelow-Wahl: Skepsis, Abneigung und große Freude," December 5, 2014, https://www.deutschlandfunk.de/reaktionen-auf-ramelow -wahl-skepsis-abneigung-und-grosse.2852.de.html?dram:article_id=305335. 
groups that "old elites were getting back into office and that the lessons of history might be banished and forgotten." 95 He claimed that two thirds of the Left Party members in Thuringia were former GDR officials and that previous staff of the state security service were among them. ${ }^{96}$

These harsh accusations were only partly justified. Two independent parliamentary Thuringian investigations in 2006 and 2012 showed that only seven of the 28 Left Party delegates had been politically active in the GDR. Only two were former Stasi officers, both of whom had been absolved by the lustration law. One of them, Frank Kuschel, is the subject of the case study below. The concern expressed by victim groups demonstrated that the wounds caused by their suffering in the traumatic past were still open, but also that they were unable to forgive their oppressors for their deeds. Their negative reaction to Ramelow's apology was a plea for a sensitive approach by the new authorities to the granting of power to members of the former GDR elite after reunification.

The members of Die Linke have a moral responsibility for the communist past because they have a certain ideological continuity with the former dictatorship, even if they were not themselves collaborators or perpetrators of the crimes of the regime. Ramelow, who is a leftist political leader without direct connections, fulfills a double function. He is a spokesman for the official state narrative and he has an obligation to respond to so far unfulfilled needs of the Thuringian population. That old elites are able to continue their careers in the new government poses a problem that needs to be solved and that is an obstacle to a new beginning.

Summarizing, the Ramelow case demonstrates a completely new approach to the burden of the past. He invites all citizens to participate in an inclusive reconciliation process. Ramelow's speech produced a number of side-effects based on its position in space and time, its historical momentum, and the internal support he received from his party. Even if the symbolic gesture of inter-personal reconciliation he offered to his friend and GDR victim, Andreas Möller, was not replicated in society or fully satisfied the representatives of victim groups, it did have a positive public effect of stimulating dialectical discourse among the population of eastern Germany.

The growing distance from injustice resulting from the rise of a new generation may help to establish an environment conducive to reconciliation and heal the still open wounds within eastern German society. The reopening of public

95 "Ramelow bittet SED-Opfer um Entschuldigung."

96 Ibid. 
discourse about the burden of the communist past in consequence of Ramelow's speech had a positive effect in that it overcame the mentality of silence, especially among perpetrators and collaborators. A lively public debate still needs to be conducted, with further dialogue on the intra- and inter-group levels, between former officials and victims, in order to break down the stereotypes held on both sides. Ramelow's speech injected a powerful moral counter-narrative into society that opposes the current trend toward radicalization on both the left and the right in eastern Germany. The growing distance in time from the historical period of communism is allowing greater objectivity with regard to the past. Apology speeches must be measured by their pragmatic impact. Purposeful programs in a German collective "memory-building industry," aimed at softening the perspectives of both victims and offenders, are needed if time alone cannot heal all wounds.

\section{Frank Kuschel: "Once a Thief, Always a Thief”}

Frank Kuschel joined the SED in 1983. He was recruited as an informant under the cover name "Fritz Kaiser" and was Deputy Mayor of Ilmenau, Thuringia with responsibility for "Interior Affairs" from 1987 to 1989. He informed against East Germans contemplating emigration, the so called Republikflüchtlinge, and disrupted the plans of families wanting to leave the country by denouncing them to the authorities. In 1990, he lost his job with the City due to the lustration policy of the post-communist government, but he soon returned to local government service. In October 1989, just one month before the Berlin wall fell, when a strong civil movement was resisting the communist authorities in the streets, he betrayed some members of the GDR opposition group Neues Forum. ${ }^{97}$ In speeches before the Thuringian Parliament in June 2006 and again in 2012, he apologized for his wrong-doing and asked his victims for forgiveness: "I made political mistakes. ... I am sorry to all those whom I have injured and I wish to apologize to third persons who were affected due to my collaboration with the Ministry of State Security." He continued, "I am open to confrontation and dialogue with victims" and pledged "to draw a line under the past."

Kuschel was born in 1961 in a small town close to Ilmenau, Thuringia in East Germany. He was one of five children. His father was an alcoholic and his mother

97 Hubertus Knabe, Honeckers Erben - Die Wahrheit über DIE LINKE (Berlin: Propyläen, 2009), 319.

98 Die Akte Kuschel, Thüringer Landtag, 4. Wahlperiode, 43. Sitzung, 13.07.2006; see Kuschel's official website with texts, http://www.frankkuschel.de/ueber_mich/die_akte_kuschel/. 
was an invalid. His family situation prevented him from pursuing a high-level career, even in the socialist system. The communist government did, however, approve Kuschel for higher education and he became a military officer in spite of his lower-class origins. ${ }^{99}$ In 1980 he joined the GDR's National People's Army and attended the military academy (Offizierhochschule) in Zittau, Sachsen. Kuschel characterizes himself as one of the "convinced" Stasi officers, who did his job "effectively." He recalled his enthusiasm to "defend the state from the capitalist enemy" in an interview with the daily paper Frankfurter Allgemeine Zeitung in 2014. ${ }^{100}$ He never publicly confessed involvement in or moral guilt for any criminal acts with regard to his victims.

In 2006 and 2012, two independent parliamentary commissions of the federal state of Thuringia reviewed his biography and proved his collaboration with the former Security Ministry. The commissions came to the conclusion that he was not suitable for public service or for a career in the politics under the new democratic system of the reunified Germany. ${ }^{101}$ Nevertheless, he was allowed to keep his mandate as a duly elected delegate in the Thuringian parliament because of a court decision in 2000 that prohibited the dismissal of former collaborators from political mandates to which they had been freely elected.

The various victim groups rejected his apology and request for forgiveness because he failed to show real repentance for his deep involvement in communist crimes. The non-governmental organization for victims, Vereinigung 17. Juni 1953, criticized his apparent lack of remorse, his refusal to renounce the unjust former regime, and his misguided betrayal of his fellow GDR citizens. ${ }^{102} \mathrm{Kuschel}$ defended his history as the result of his being a "convinced political socialist" and asserted his "political re-orientation after 1989/90." The latter claim was dismissed by the victim groups because it completely ignored the suffering of his victims. The majority of the public doubted the truth of his claimed rejection of the old ideology. ${ }^{103}$

The chief of Kuschel's new party, Bodo Ramelow, maintained a close personal relationship with the former Stasi officer and did not disavow him before

99 Lydia Rosenfelder, "Sein Deckname war Fritz Kaiser," Frankfurter Allgemeine Zeitung, November 26, 2014, http://www.faz.net/aktuell/politik/inland/ex-stasi-im-fuer-die-linke-im-thueringerlandtag-13280463.html.

100 Ibid.

101 "Flugblatt: Ich will keine Rache. Aber Einsicht, Reue, Schamgefühl sind Kuschel fremd," Official homepage of the victim's organization Vereinigung 17. Juni 1953 e.V., May 24, 2014, https:// 17juni1953.wordpress.com/tag/frank-kuschel/.

102 Ibid.

103 Rosenfelder, “Sein Deckname," 3. 
being elected the federal state's minister president, as the Frankfurter Allgemeine Zeitung pointed out. Instead of showing remorse, Kuschel evidenced a lack of understanding for the public reaction to his apology. According to the motto "once a thief, always a thief," most of his fellow citizens simply did not believe in his change of political attitude and behavior. ${ }^{104}$ In spring 2017, Kuschel spoke to a tenth-grade history class, where he was peppered with critical questions about his past. He gave the class a first-hand account of the life of a Stasi operative. ${ }^{105}$ Kuschel's insider perspective as a collaborator of state's repression gave first hand insights into the mechanisms of communist dictatorship. At the same time, his witness' perspective became critically embedded into an anti-totalitarian interpretation of the communist crimes. This approach was one of only a few attempts at an inter-generational and inter-group reconciliation process between former perpetrators and later born, non-affected generations.

Recalling Jaspers's four dimensions of guilt, Kuschel's failure to admit his guilt limited his chances of being forgiven. If former GDR collaborators like Kuschel are unwilling or unable to accept personal responsibility for their personal crimes and refuse to apologize and adopt the victims' perspective as the predominant narrative over the past, political apology speeches lose their positive effect on society.

\section{Conclusion}

This paper has investigated the role and the impact of political apology speech in post-1989 eastern Germany, with special focus on its after-effects, such as mobilizing social and discursive processes to reveal and reinterpret past injustices under the GDR communist regime. The empirical case studies feature officials who have certain continuity with the former GDR regime - either as members of the former political elite or as a high official of the SED's successor party, Die Linke. The German case studies confirm the conclusion reached in the international research literature that speeches of political apology provoke public discourse and assist in the collective memory-building process. These effects are illustrated by the vibrant debates that followed the three speeches about the proper interpretation of the injustices of the former GDR dictatorship.

104 Ibid.

105 Hanno Müller, "Ich war Stasi-IM aus Überzeugung: Frank Kuschel stellt sich Fragen von Schülern," Thüringer Allgemeine Zeitung, April 04, 2017, http://www.thueringer-allgemeine.de /web/zgt/politik/detail/-/specific/Ich-war-Stasi-IM-aus-Ueberzeugung-Frank-Kuschel-stellt -sich-Fragen-von-Schueler-378518893. 
All three cases of apology speech had a positive effect in terms of reopening public discourse about the communist past. Even if former GDR officials failed in some cases to achieve their intended goal of being forgiven and were unable to reconcile with former dissidents, public awareness of the GDR regime's injustices increased as a result of their symbolic political gestures. The cases presented here were individual choices to apologize and to acknowledge past injustice. They were featured in press reporting numerous times. Moreover, they illustrate the important role of moral agency to the promotion of a reconciliatory message, as well as the importance of the historical time frame, which created an environment conducive to the opening of a discussion about the past. Finally, all three cases demonstrate progress in East German society toward reopening of a critical debate about the country's communist past.

Each of the three cases we examine here exemplifies a different relationship with time and space and a particular relationship of the individual with the past injustice that was addressed in their speech of apology. As the case of Bodo Ramelow, the West German-born Minister President of Thuringia, demonstrates, the more time that passes from the communist injustices, the lesser the chances that an apology will be accepted. All three cases of political apology speech involve different levels of individual and official responsibility on the part of the person who delivered it, in the sense of the categories of political and moral guilt set forth by Jaspers. Apologies delivered by persons who are directly or indirectly responsible for the injustices differ with regard to what their author believes needs to be reconciled. The results of a political apology, such as its impact on interpersonal and intra-national reconciliation between perpetrators and victims, depends first and foremost on the victims' willingness to accept the apology. If the offender shows real remorse and acknowledges the suffering of the victims under a dictatorship, he or she gains credibility, which increases the willingness of the victims to accept the apology.

The case of Frank Kuschel shows the moral and practical limits of reconciliation. His inability to demonstrate true, deep remorse, to confess his individual crimes and moral guilt, and his refusal to distance himself from the GDR's crimes were met with a negative public response. As a result, his plea for integration into the new democratic society was turned down. This case confirms that the personal dimension of an apology defines the extent to which a perpetrator can be forgiven by victim groups.

Rebuilding or transforming personal relationships between former opponents depend primarily on the decision of the individual. The self-interest of a political entity often differs from that of the individuals it represents, i.e., there 
is often a difference between the official state narrative and individual private opinion. Sometimes personal narratives and public narratives about a troubled past remain irreconcilable and open wounds are unable to heal. The degree of public acceptance of a speech of apology gives insight into how strongly different narratives about the past continue to conflict with each other.

Each of the three cases cited here confirms the multiplier effect of a speech of political apology in that it raised public awareness about past communist injustices, independently of their success in promoting reconciliation on the inter-personal or inter-group level. A direct correlation between a speech of apology and progress toward reconciliation can mostly be seen on the level of the individual, and not so much on the national level. Progress in reconciliation between groups can be increased if a public forum, such as the public hearings held in the German Federal Parliament, allows a direct encounter between perpetrators and their victims.

The case of Bodo Ramelow shows that attempting to reform the overall culture of memory increases the credibility and acceptance of a speech of political apology, along with public trust in political authority. The grant of an ideological pardon to a fallen totalitarian regime and its elites must be approached critically and with respect for the perspectives of its victims. General forgiveness for communist injustices can only be achieved if there is a public political consensus that acknowledges the suffering of the victims and respects democratic norms and values. Two of the three case studies above (Keller and Ramelow) showed positive impact on the inter-personal and intra-group levels, as well as between groups of victims, civil rights activists and offenders. That finding suggests that if Dasse's criteria for a successful apology are fulfilled, a more positive response from victim groups can be achieved and the probability that a political apology will be accepted by society increases.

The hypothesis that the earlier an apology is made, the better it will support a reconciliation process is not confirmed by the above findings. Nevertheless, the examples of Ramelow and Kuschel seem to confirm the international observations that a shift in perspective a generation after the democratic transition allows for a more pluralistic discourse on the past and increases the chances for a successful reconciliation between the antagonist groups. Furthermore, a public apology needs the support of verified historical facts about past crimes, which politicians can address in order to redefine the collective national awareness and memory. The Ramelow case study shows that internal acceptance of guilt by the collaborator group raises the chances for the acceptance of an apology on the public national level. Even though the German victim and civil activist 
groups still harbored doubts about Ramelow's and his party's sincerity and were less than willing to reconcile, his rehabilitation gesture raised the moral credibility of the new government with eastern German society. Ramelow's speech established a counter-narrative in the local and national arenas that allowed consideration of new paths toward reconciliation. While Ramelow and Keller were able to put distance between themselves and the injury done by the former GDR regime, Kuschel's case is different. Because of his personal involvement as an informant for the agencies of state repression, he faced greater skepticism from victim groups. His failure to show remorse or even to admit that the state committed any crimes, and his failure to address his individual victims directly, did not inspire his victims. His example can therefore be interpreted as a failed speech of political apology.

With the growing distance in time from past injustices of the GDR, the perspective of Die Linke on the overall anti-totalitarian consensus in Germany has changed. This is evidenced by the party's full-scale acceptance of responsibility for crimes committed under the communist regime and its acknowledgment of the suffering of the regime's victims. Apology speeches have brought about progress in the internal reconciliation of the old GDR political elite with its past crimes. In some cases, symbolic gestures of apology created an opportunity to open up the public landscape to reconciliation. Keller's case demonstrates how institutions like parliamentary commissions can create an atmosphere of reconciliation between oppressor groups and dissidents and promote empathy for different perspectives through dialogue.

Speeches of political apology are transmitters of a message of reconciliation that bridges the public and private spheres, and also the past and present. They can stimulate public discourse about a troubled past and create awareness of past injustices within the collective memory of a nation. A reconciliatory environment initiated by society's moral leadership opens a window of opportunity to learn from others, to reinterpret the past, and to build up a shared narrative about a contested past. 